\title{
腰痛の有無にて比較した腹部筋群の筋厚 \\ 一超音波画像を使用して一 \\ Comparison of the Thickness of Abdominal Muscles between Subjects With and Without Lumbar Pain Using Ultrasound Images
}

村上 幸士1,2)＼cjkstart桜庭 景植3)＼cjkstart永井 康一4)

\author{
TAKASHI MURAKAMI ${ }^{1,2)}$, KEISHOKU SAKURABA ${ }^{3)}$, KOICHI NAGAI $^{4)}$ \\ 1) Department of Physical Therapy, School of Health Science, Kyorin University: 476 Miyasita-Cho, Hachioji-Shi, Tokyo 192- \\ 8508, Japan.TEL+81 42-691-0011EX4534 E-mail 39takashi-m@ks.kyorin-u.ac.jp \\ 2) Department of Sports Science, Graduate School of Health and Sports Science, Juntendo University \\ 3) Department of Sports Medicine, Graduate School of Health and Sports Science, Juntendo University \\ 4) Department of Radiology, Tamura Surgical Hospital
}

Rigakuryoho Kagaku 25(6): 893-897, 2010. Submitted May 24, 2010. Accepted Jul. 12, 2010.

\begin{abstract}
Purpose] This study was performed to examine the correlation between lumbar pain and abdominal muscle thickness. [Subjects] The subjects were 64 males. [Methods] The subjects were divided into 3 groups based on the results of an interview about lumbar pain. Images of the transversus abdominis, internal abdominal oblique muscle, and external abdominal oblique muscle at rest were obtained using ultrasonography. [Results] The thickness of the transversus abdominis in the group of subjects who had visited a hospital for lumbar pain was less than other groups. [Conclusion] It was suggested that the experience of lumbar pain was related to a decrease in the thickness of the transversus abdominis at rest due to reduced muscular activity and an increase in the thickness of the internal and external abdominal oblique muscles at rest due to excessive muscular activity.
\end{abstract}

Key words: lumbar pain, transversus abdominis, ultrasound image

要旨：〔目的〕腰痛経験の有無と腹部筋群との関連を明らかにすることを目的とした。〔対象〕平均年齢 $23.7 \pm 3.3$ 歳 の男性 64 名である。〔方法〕問診を行い, 腰痛経験の有無にて 3 群に分類した。また, 超音波診断装置にて安静時 の腹横筋・内腹斜筋・外腹斜筋を測定し, 筋厚の差を腰痛経験の有無にて比較し, 分析した。〔結果〕腰痛にて受 診経験のある群は, 腰痛を認めるが受診経験のない群および腰痛経験のない群と比較して腹横筋筋厚が低值であ り, 他筋は有意差がなかった。〔結語〕腰痛経験が有ることは, 腹横筋の筋活動低下による安静時の筋厚減少およ び内腹斜筋と外腹斜筋を合わせた表在筋の過剩な筋活動による安静時の筋厚増大と関連することが示唆された。 キーワード：腰痛，腹部筋群筋厚，超音波画像

1) 杏林大学 保健学部理学療法学科運動障害系理学療法学研究室 : 東京都八王子市宮下町476（广192-8508） TEL 042-691-0012 (4534)

2) 順天堂大学大学院 スポーツ健康科学研究科スポーツ科学博士後期課程

3) 順天堂大学大学院 スポーツ健康科学研究科スポーツ医学

4) 医療法人清恵会田村外科病院＼cjkstart放射線部門

受付日 2010年5月24日＼cjkstart受理日２010年7月12日 


\section{I.はじめに}

近年では，体幹一骨盤の安定化を目的として体幹筋 群のトレーニングや, そのメカニズムを解明するため の研究が行われている。その安定化における主な機械 的役割を基に体幹筋群を, 深部（中心部）に位置し㑒 椎分節を安定させるローカル筋システム（腹横筋や腰 部多裂筋など）と, 表在に位置し脊椎全体としての運 動を与え, 脊柱に起始停止を持たないグローバル筋シ ステム（腹直筋や外腹斜筋など）に分類している1)。

その中の深部に位置する腹横筋に関しては, 健常者 を対象に超音波診断装置を用いた研究2,3)が最近行われ ているが，腹横筋より表在に位置する内腹斜筋，外腹 斜筋との関連および腰痛との関連を報告した研究は少 ない。一方, 筋電図を用いた先行研究では, 腹横筋お よび内腹斜筋, 外腹斜筋の動作時の筇活動が腰痛の有 無により異なると報告されている4-6)。また，多裂筋の 断面積を超音波イメージングにて測定した研究では, 腰痛側の断面積が減少していたと報告されている7)。こ れらの報告から, 腰痛の有無は, 腹横筋および内腹斜 筋, 外腹斜筋の安静時の筋断面積つまり各筋厚に影響 を及ぼす可能性があると考えた。

また，超音波診断装置による測定の信頼性に関する 研究にて, 背臥位における安静時での測定はより高い 信頼性を得ることができると報告されているが8), 動 作中の超音波の測定には，高い技術が必要となり，信 頼性一の疑問の声もある。さらに, 今回使用した超音 波診断装置は, 通常臥位で行い, 腹部筋群の測定も背 臥位および安静時の測定での信頼性が最も高いとされ ている9-11)。

以上より, 腰痛の有無に関連して, 動作時に異なる 働きをするといわれている腹横筋および内腹斜筋, 外 腹斜筋は, 安静時の筋厚でも異なると考え, 腰痛経験 の有無と腹部筋群 (側腹部 3 筋) との関連を明らかにす ることを本研究の目的とした。その方法として, MRI などと比較して簡便であり, リアルタイムに測定でき る超音波診断装置を使用し, より信頼性の高い安静背 卧位で測定した超音波画像にて比較・検討した。

\section{II. 対象と方法}

1. 対象

研究に対して文書にて同意を得られた男性64名（平 均年齢 : $23.7 \pm 3.3$ 歳, 平均身長 : $171.3 \pm 6.2 \mathrm{~cm}$, 平均 体重：62.9 $\pm 7.0 \mathrm{~kg}$ ) を対象とした。なお，倫理的な配
表1 群分けした対象者の基本特性

$(\mathrm{n}=64)$

\begin{tabular}{ccccc}
\hline & 人数(名) & 年齢(歳) & 身長 $(\mathrm{cm})$ & 体重 $(\mathrm{kg})$ \\
\hline A群 & 16 & $23.2 \pm 3.8$ & $170.1 \pm 5.6$ & $63.2 \pm 7.3$ \\
B群 & 19 & $23.2 \pm 3.1$ & $170.6 \pm 6.1$ & $61.8 \pm 8.3$ \\
C群 & 29 & $24.0 \pm 3.2$ & $171.0 \pm 6.6$ & $62.7 \pm 7.8$ \\
\hline
\end{tabular}

数值は, 平均值士標準偏差. 群間の有意差 : N.S.

$\mathrm{A}$ 群 : 腰痛にて受診経験のある群

B 群 : 腰痛を認めるが受診経験のない群

$\mathrm{C}$ 群 : 腰痛経験のない群

慮や研究内容, 目的, 方法および注意事項などを記載 した研究同意書を作成し，研究責任者が対象者に説明 を行い，十分に研究に対し理解を得た上で必ず同意を 求め, 直筆での署名を得た。

\section{2. 方法}

腰痛に対する問診を行い, 急性腰痛, 腰部からの神 経症状, 慢性腰痛などで受診経験のある群（以下，A 群), 長時間の立位・坐位での腰痛やときどき腰痛が出 現したことはあるが受診経験のない群（以下，B 群）, 腰痛を経験したことのない群（以下， $\mathrm{C}$ 群）に分類し た。その結果, 被験者 64 名は, A 群 16 名, B群 19 名, C 群 29 名に分類された（表 1$)$ 。

超音波診断装置での測定は，まず，背臥位にて臍レ ベルの水平線と左前腋窝線上の交点から前内方にマー キングを行った。その部位にプローブを置き, 腹横筋, 内腹斜筋, 外腹斜筋の安静時をイメージング (各 10 秒 間）し，動画画像をDVD レコーダー（SONY 製）に記 録した。なおこの測定は背臥位で行い, Bモードにて デジタル超音波診断装置（東芝社製 $\mathrm{SSA}_{\mathrm{TM}}-390 \mathrm{~A}$ Power vision 8000)，8 MHz プローブ（東芝社製リニア形）を使 用した。また, 測定中は, 通常呼吸を行うように指示した。

記録した動画画像より画像編集ソフトWin DVD (コー レル株式会社）を用いて, 筋厚が最小となる安静吸気 位に統一し, 静止画像を抽出した。その後, 画像解析 ソフト Image J（米国国立衛生研究所）を用いて, 腹横 筋, 内腹斜筋, 外腹斜筋の筋厚を筋の走行と垂直 $\left(90^{\circ}\right)$ になるように筋膜間の距離を計測した（図1)。

検者 1 名が全対象 64 名に対し，測定・計測を 2 回ずつ 行い，同一対象者に対する 2 回の測定・計測は別の日に 行った。1 回目と 2 回目の測定に対し, 級内相関係数 Intraclass correlation coefficient（以下，ICC）（1，1）を使 用して測定值・計測值の検者内信頼性の確認を行った。 また，測定・計測した腹横筋，内腹斜筋，外腹斜筋の 


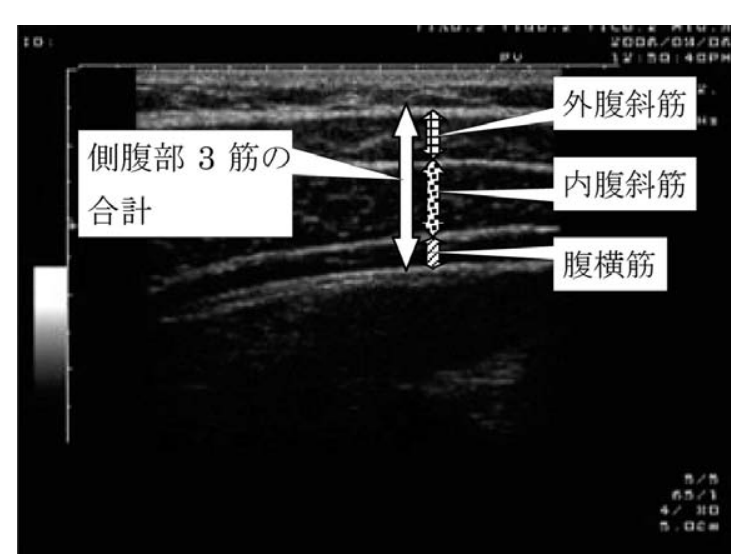

図1 筋厚（側腹部3筋）の測定部位

筋厚の結果を, A 群, $\mathrm{B}$ 群, $\mathrm{C}$ 群の 3 群で, 一元配置分 散分析およびBonferroniの多重比較検定を用いて比較し た。統計処理には, SPSS version 10.0J for Windows (エス・ ピー・エス・エス株式会社）を用いて行い，5\%未満を 有意水準とした。
表2 2回の測定・計測における検者内信頼性の結果 $(\mathrm{n}=64)$

\begin{tabular}{lccc}
\hline $\begin{array}{c}\text { 腰痛にて受診 } \\
\text { 経験のある群 } \\
(\mathrm{n}=16)\end{array}$ & $\begin{array}{c}\text { 腰痛を認めるが } \\
\text { 受診経験のない群 } \\
(\mathrm{n}=19)\end{array}$ & $\begin{array}{c}\text { 腰痛経験の } \\
\text { ない群 } \\
(\mathrm{n}=29)\end{array}$ \\
\hline 腹横筋 & 0.95 & 0.96 & 0.95 \\
内腹斜筋 & 0.93 & 0.94 & 0.94 \\
外腹斜筋 & 0.94 & 0.94 & 0.96 \\
\hline
\end{tabular}

数值は, 級内相関係数 ICC $(1,1)$ の測定值を表す

\section{III. 結 果}

2 回の測定・計測での検者内信頼性を確認した ICC (1，1）の結果は，腹横筋が $0.95 \sim 0.96$, 内腹斜筋が 0.93 〜0.94, 外腹斜筋が $0.94 \sim 0.96$ であり，それぞれLandis らの分類 ${ }^{12)} に て$ almost perfect以上の相関を認めた(表2)。 腹横筋の筋厚は, $\mathrm{A}$ 群-C群間, $\mathrm{A}$ 群-B群間で有意差 $(\mathrm{p}<0.05)$ がみられ，いずれも $\mathrm{A}$ 群で低值を示した。な お, $\mathrm{B}$ 群一C 群間では有意差はみられなかった。内腹斜 筋および外腹斜筋の筋厚は, $\mathrm{A}$ 群， $\mathrm{B}$ 群， $\mathrm{C}$ 群間でいず れも有意差はみられなかった。表在筋の筋厚（内腹斜 筋と外腹斜筋の合計）は， $\mathrm{A}$ 群 $-\mathrm{C}$ 群間， $\mathrm{A}$ 群-B群間で

表3 腰痛・受診経験群，腰痛経験群，腰痛経験なし群における腹横筋，内腹斜筋, 外腹斜筋の筋厚の比較

$(n=64)$

\begin{tabular}{lccc}
\hline & $\begin{array}{c}\text { 腰痛にて受診 } \\
\text { 経験のある群 } \\
(\mathrm{n}=16)\end{array}$ & $\begin{array}{c}\text { 腰痛を認めるが } \\
\text { 受診経験のない群 } \\
(\mathrm{n}=19)\end{array}$ & $\begin{array}{c}\text { 腰痛経験の } \\
\text { ない群 } \\
(\mathrm{n}=29)\end{array}$ \\
\hline 腹横筋 & $3.0 \pm 0.3 *$ & $3.7 \pm 0.4$ & $3.8 \pm 0.8$ \\
内腹斜筋 & $9.7 \pm 1.9$ & $8.2 \pm 1.3$ & $8.3 \pm 1.4$ \\
外腹斜筋 & $6.7 \pm 1.3$ & $5.5 \pm 1.0$ & $5.9 \pm 1.1$ \\
内腹斜筋十外腹斜筋 & $16.4 \pm 2.3 *$ & $13.7 \pm 1.7$ & $14.2 \pm 1.8$ \\
(表在筋) & & & \\
\hline
\end{tabular}

数值は, 平均值士標準偏差（単位 : mm）を表す

* : $\mathrm{p}<0.05$
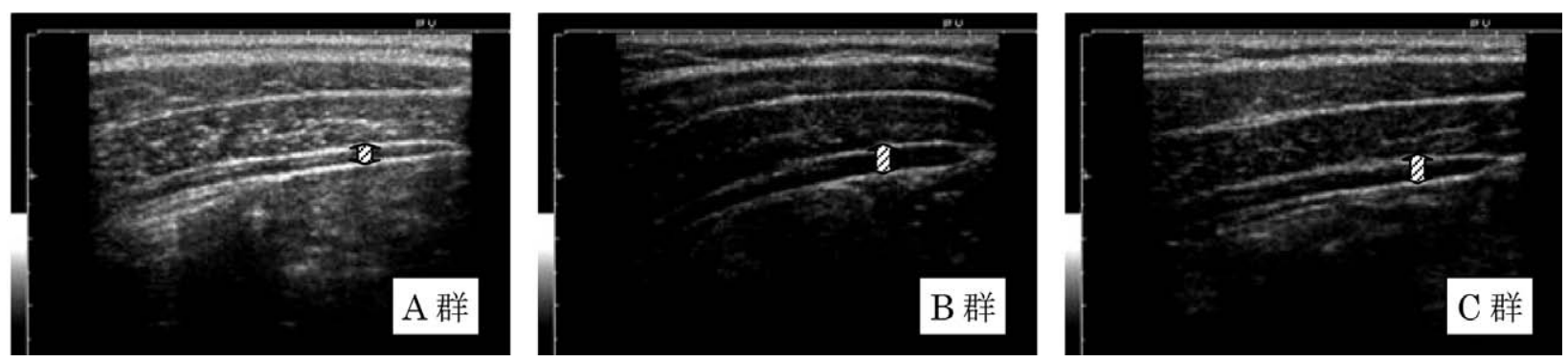

図2 各群（A〜C群）における超音波画像 
有意差（ $\mathrm{p}<0.05 ）$ がみられ，いずれも A 群で高值を示し た。なお, B 群-C群間では有意差はみられなかった（表 3) (図2)。

\section{IV. 考 察}

先行研究の報告から, 腹横筋および内腹斜筋, 外腹 斜筋の動作時における筋活動は腰痛経験の有無にて異 なり, これは, 安静時の筋断面積を反映する各筋厚に も影響を及ぼす可能性があると考え, 本研究を実施した。

腰痛患者は, 上肢および下肢のあらゆる運動方向に おいて, 健常者と比較して動作時に腹横筋の筋活動遅 延および低下が起こる4)。また, 深部筋の筋活動低下お よび遅延などで起こるローカルシステムの障害は腰痛 で最も発生しやすいと報告されている2)。さらに, Teyhen

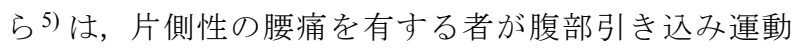
を行う間, 腹横筋筋厚の増大は少なかったと述べてい る。これらの知見より, 腰痛によって腹横筋の筋活動 が低下し, その活動中の筋厚にも影響がみられると考 えた。また, 各動作時に筋活動が異なることは, 安静 時の筋厚にも影響するのではないかと考え, 今回, 安 静背臥位で測定した超音波画像にて, その筋厚を計測 した。一方, Radebold ら ${ }^{13)}$ は, 軽度な課題中に起こる グローバル (表在) 筋の過剩な同時収縮は, 腰痛患者 における体幹筋の不適切なコントロールの指標になる と述べている。また, Hodgesら ${ }^{6)}$ は, 実験的に誘導され た腰痛の研究において, 腰痛が増加すると, 少なくと も 1 つのグローバル筋の活動が増加し, 健常者と比較 して, 内腹斜筋, 外腹斜筋の過剩な同時収縮が起こる と述べている。これらの知見より, 腰痛によって内腹 斜筋, 外腹斜筋の筋活動が増加し, その活動中の筋厚 にも影響がみられると考えた。また, 各動作時に筋活 動が異なることは, 安静時の筋厚にも影響するのでは ないかと考え, 今回, 安静背臥位で測定した超音波画 像にて, それらの筋厚を計測した。

結果は, 腰痛経験の有無に対する深部筋（腹横筋） と表在筋（内腹斜筋，外腹斜筋）の筋厚の相違および 安静時の筋厚は上記 2 点の知見と一致するものであっ た。すなわち, 腰痛経験の有無にて腹部笳群の筋活動 が異なり, 安静時の各筋の筋厚に相違がみられた。よっ て, 腰痛経験（受診経験のある）の有無による比較に て, 腹横筋および内腹斜筋, 外腹斜筋の筋活動に相違 がみられ, 腰痛にて受診経験のある群は, 脊椎分節を 安定させる腹横筋の筋活動低下および遅延が起こり, それを補うために脊椎全体としての運動を与える内腹
斜筋，外腹斜筋の過剩な筋活動がみられたと考えられ る。つまり, 腰痛経験が有ることは, 腹横筋の筋活動 低下による安静時の筋厚減少および内腹斜筋, 外腹斜 筋の過剩な筋活動による安静時の筋厚増大と関連する ことが示唆された。今回の結果では, 腰痛経験との関 連が示唆されたが, 腰痛の程度, 罹患期間, 症状の部 位および収縮時を含めた測定など詳細な調查および分 析にて異なる結果となる可能性も否定できないことか ら, これらの調查・分析は今後の課題である。

今回測定した腹横筋およびその周囲筋膜は, 深部に 位置するため超音波診断装置での測定が必要となる。 その超音波診断装置でイメージングされた画像は, 筋 膜をはっきりとらえることができ, 前外側腹壁の 3 つ の筋を明確に区別することができている2)。今回の測 定でも，筋膜をはっきりイメージングでき，3つの筋を 明確に区別できた。また, McMeeken ら ${ }^{3)}$ は, 腹横筋の 筋厚の変化と筋電図との関連性を調べ, 超音波診断装 置で測定した筋厚の増加に比例して筋電図で測定した 筋活動も増加し, 高い相関（r=0.87）を報告している。

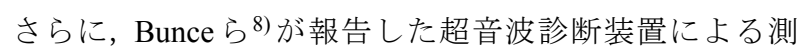
定の信頼性に関寸る研究では, 立位, 歩行時の級内相 関係数 (以下, ICC) が ICC $=0.88$ で, 背臥位では $\mathrm{ICC}=0.94$ を示している。このように, 背臥位, 安静時での測定 はより高い信頼性を得ることができており, 今回の測 定も, 安静背臥位にて行った。その中で, 今回の研究 は, 測定・計測日を変え, 全測定・計測を同条件にて2 回実施した。その結果, ICC $(1,1)$ にて, almost perfect 以上の相関 ${ }^{12)}$ を認めた。また, Fleiss ${ }^{14)}$ が ICC $=0.75$ 以上 あれば信頼性は良好であると述べているように, 安静 背臥位での腹横筋, 内腹斜筋, 外腹斜筋を測定した超 音波画像の高い信頼性を確認できた。その要因として, 第一に, 臍レベルの水平線と左前腋窩線上の交点から 前内方にマーキングしたことで, プローブ位置の指標 となり, 最終的な位置は, 画像での確認により決定し, 位置を一定にできたことである。次に，測定した動画 画像より, 呼吸による変動で最も筋厚が小さくなる安 静吸気位に統一し, 静止画像を一定に抽出できたこと である。最後に, 抽出した静止画像から筋膜間の距離 を計測する際も計測ラインが各筋の走行と垂直 $\left(90^{\circ}\right)$ になるようにし, さらに, 計測部位は, 上下の筋膜が 平行となる部位の中央で, かつ, 筋膜間の距離が最大 となる部位に統一を図ったことである。

以前より腰痛と腹部筋群との関連に関して, 多くの 見解が示されている。しかし，多くは，表在筋である 腹直筋や脊柱起立筋群と腰痛との関連について述べ, 
腹横筋などの深部筋と腰痛との関連を超音波診断装置 による測定にて述べた報告は少ない。また, 今回行っ た安静背臥位での超音波画像の測定は, 他の肢位と比 較して信頼性や再現性は高いと言える。この測定によ り本研究では, 腰痛経験の有無と深部筋を含めた腹部 筋群の関連を示すことができた。さらに, 今回行った 安静時の筋厚測定は, 各筋の状態 (肥大, 萎縮など) や 治療などの効果判定にも使用できる可能性を示唆した。

\section{引用文献}

1) Bergmark A: Stability of the lumbar spine. A study in mechanical engineering. Acta Orthop Scandi Suppl, 1989, 230: 20-24.

2) Richardson C, Hodges PW, Hide J, et al.: Therapeutic exercise for lumbopelvic stabilization: a motor control approach for the treatment and prevention of low back pain. Churchill Livingstone, New York, 2004, pp77-92.

3) McMeeken JM, Beith ID, Newham DJ, et al.: The relationship between EMG and change in thickness of transversus abdominis. Clin Biomech, 2004, 19(4): 337-342.

4) Hodges PW, Richardson CA: Delayed postural contraction of transversus abdominis in low back pain associated with movement of the lower limb. J Spinal Disord, 1998, 11(1): 46-56.

5) Teyhen DS, Bluemle LN, Dolbeer JA, et al.: Changes in lateral abdominal muscle thickness during the abdominal drawing-in maneuver in those with lumbopelvic pain. J Orthop Sports Phys
Ther, 2009, 39(11), 791-798.

6) Hodges PW, Moseley GL, Gabrielsson AH, et al.: Experimental muscle pain changes feedforward postural responses of the trunk muscles. Exp Brain Res, 2003, 151(2), 262-271.

7) Hides JA, Stokes MJ, Saide M, et al.: Evidence of lumbar multifidus muscle wasting ipsilateral to symptoms in patients with acute/ subacute low back pain. Spine, 1994, 19(2), 165-172.

8) Bunce SM, Moore AP, Hough AD, et al.: M-mode ultrasound: a reliable measure of transversus abdominis thickness? Clin Biomech, 2002, 17(4), 315-317.

9) Mannion AF, Pulkovski N, Gubler D, et al.: Muscle thickness changes during abdominal hollowing: an assessment of betweenday measurement error in controls and patients with chronic low back pain. Eur Spine J, 2008, 17, 494-501.

10) Stetts DM, Freund JE, Allison SC, et al.: A rehabilitative ultrasound imaging investigation of lateral abdominal muscle thickness in healthy aging adults. J Geriatr Phys Ther, 2009, 32: 16-22.

11) Koppenhaver SL, Hebert JJ, Fritz JM, et al.: Reliability of rehabilitative ultrasound imaging of the transversus abdominis and lumbar multifidus muscles. Arch Phys Med Rehabil, 2009, 90: 87-94.

12) Landis JR, Koch GG: The measurement of observer agreement for categorical date. Biometrics, 1977, 33: 159-174.

13) Radebold A, Cholewicki J, Panjabi MM, et al.: Muscle response pattern to sudden trunk loading in healthy individuals and in patients with chronic low back pain. Spine, 2000, 25, 947-954.

14) Fleiss JL: The Design and Analysis of Clinical Experiments. John Wiley \& Sons, New York, 1986, pp1-32. 